Vol. 1, 2019

\title{
The mobilizing power of Facebook in the campaign for the ongoing presidential elections 2019 in Romania - candidate Viorica Dăncilă
}

\author{
Nicoleta Bercaru, Sorin Bercaru \\ Master - The Management of Public Institutions, Faculty of Law and Administrative \\ Sciences, "Ovidius" University of Constanta, Romania \\ nikobercaru@gmail.com
}

\begin{abstract}
In an era of communication, technology and dependence on online social networks, Social Media are communication tools that public administrations and especially political actors must learn to use efficiently. Our objective are: (1) analysis of key performance indicators (KPIs) that facilitate the communication on Facebook of the PSD candidate, Viorca Dăncila, Coparativ with the PNL candidate, Klaus Werner Iohannis, during the presidential election campaign, (2) identify and analyze messages that generate high commitment rate from the utiizers, (3) analyzing the dominant emotions generated by the online audience.
\end{abstract}

Keywords. Facebook, campaign, presidential elections, Viorica Dancila

\section{Argument}

In an era of communication, technology and dependence on online social networks, Social Media are communication tools that public administrations and especially political actors must learn to use efficiently.

According to the Federal council Web Managers, Social Media and WEB 2.0 are framework terms that include various activities that integrate technology, social interaction and content creation. Socia Media uses several new technologies, such as: blogs, wikis, photo and video sharing, podcasts, social networks, mashups and virtual worlds. (apud. Tasențe, 2019) With the help of online social networks, the dissemination of political information has been reached in all its nodes (Tasente, 2019), so that citizens come to participate and become increasingly politically and civic-active.

In the context in which politicians understand the psychology of the user in Socia Media and behave accordingly, the active presence in an online social network can help to influence the public, because social networks can be a very good channel To propagating messages and can interact more efficiently with online community opinion leaders. However, these benefits are only activated if the members of the network are personally involved in the debate and are not bombed by artificial messages written by a third person, who cannot feel the needs of the public as a politician or communicators do in Around it (Tasențe, 2019)

\section{Research objectives}

O1: Analysis of key performance indicators (KPIS) that facilitate the communication on Facebook of the PSD candidate, Viorca Dăncila, Coparativ with the PNL candidate, Klaus Werner Iohannis, during the presidential election campaign. 
O2: Identify and analyze messages that generate high commitment rate from the utiizers.

O3: Analyzing the dominant emotions generated by the online audience.

\section{Research Methodology}

In order to achieve the objectives of the research, quantitative and qualitative research methods were used, through the analysis of the Facebook communication campaign, during the ongoing electoral campaign. The analysis was done by comparing the candidates of the two largest parties in Romania, Viorica Dăncila (PSD) and Klaus Werner Iohannis (PNL) and the independent candidate Alexandru Cumpănaşu. The campaign began on 12 October 2019, the start date of this study, which is considering the analysis of the last 28 days (14 September - 12 October), and the elections are due to take place on November 8th and November 10th in the country.

\section{Centralization and data analysis}

Fans of the three candidates and demographical profile of Facebook users in Romania

The biggest number of fans on the Facebook page is found at K. W. Iohannis $(1,845,198)$, followed by Alexandru Cumpănaşu $(292,232)$ and Viorica Dăncilă $(61,153)$.

Thus, we note that K. W. Iohannis has 6.32 times more fans than Al. Cumpănaşu and 30.17 times more than Viorica Dăncilă.

According to Facebrands.ro in Romania there are about 9.6 million Facebook accounts, which means that $19.22 \%$ of users are fans of the candidate K. W. Iohannis, $3.04 \%$ are fans of the candidate Al. Cumpănaşu and only $0.64 \%$ are fans of the candidate Viorica Dăncila.

Moreover, from a demographical point of view, $50 \%$ of Facebook users in Romania are men, and $50 \%$, women. The predominant age categories are $25-34$ years, $26.83 \%$, followed by $18-24$ years, $21.47 \%, 35-44$ years, $21.15 \%$. At the opposite pole we find the following age categories: $45-54$ years, $12.63 \%, 55-64$ years, $6.16 \%$ and $65+, 2.53 \%$ (Tasențe, 2019).

The commitment rate of fans and decentralization of political information in their social groups

Fans of the candidate Al. Cumpănaşu were the most active in commenting and redistributing the information provided by him. ASTFE, total reactions, comments and redistributs sum up 1,443,246, that is, an $18 \%$ commitment rate. On the other hand, the fans of $\mathrm{K}$. W. Iohannis generated an interaction rate of $0.48 \%$, which may seem very small, but it comes from a number of 1,845,213 fans with a total reaction, commentary and redistributions of 248,238 . At the same time, candidate Viorica Dăncila has a rate of 9.8\% interaction, from a total reaction, commentary and redistributions of 158 . 157. In view of the difference between the number of fans on the FB-dăncile page and the number of reactions, there is the possibility of increasing the number of fans and with it an increase in the analysed performance indicators.

It is extremely important that all the information of the analysed pages has been redistributed (disseminated) and to socially disinterested or politically uninvolved groups, a virgin fief, being the undecided in terms of voting.

From this point of view, Tanase Tasente (2019), in the article named Social Media and personalised political communication, show that "through this mechanism, political information reaches the fan, its strong links, so that the credibility of the information increases Considerably. And as regards the dissemination of political information in Social Media, the National Liberal party leads the online communication campaign with 105,000 redistributions. On the other hand, the USR received 48,000 redistributions, and those on the PSD page, only 13,000 redistributions".

\section{Conclusions}

Following the above analysis, it is advisable:

1. Identify as many PSD members as possible to the FaceBook page holders and their guidance to become a Fan page VD (PSD Constanta $=11000$ members)

2. Identification of at least 10 people who have IT knowledge, who will identify large and large groups, will infiltrate, in order to distribute and support the PSD candidate, V. D. All these 
people will comment in groups to support their Each other (OBS. It is necessary that in these groups there are more than 3 such persons, because there is a risk of exclusion from the group, if there are few and the group is hostile. It is also well known that in group psychology there is the idea of contamination.)

3. Creating short, emotional messages that refer to the fears of the population, referring to the cuts in income and their transfer.

4. Ridiculing political enemies.

5. Creating very short messages marking all the PSD achievements during the Dăncilă government. Each day, one-two such messages will be viralized.

6. Aggressive combat of false themes, such as the theme of expensive.

Posts with highest commitment rate in the last 28 days (September 14th - October 12th)

\begin{tabular}{|c|c|c|c|c|c|c|c|c|c|c|c|c|c|}
\hline \multirow{2}{*}{$\begin{array}{c}\text { Candida } \\
\text { te }\end{array}$} & \multirow[t]{2}{*}{ Subject } & \multirow{2}{*}{$\begin{array}{l}\text { Posting } \\
\text { type }\end{array}$} & \multirow{2}{*}{$\begin{array}{l}\text { Date/ } \\
\text { hour }\end{array}$} & \multicolumn{7}{|c|}{ Engagement } & \multirow{2}{*}{$\begin{array}{l}\text { Comm } \\
\text { ents }\end{array}$} & \multirow[t]{2}{*}{ Shares } & \multirow[t]{2}{*}{ Views } \\
\hline & & & & 16 & & $(2$ & (2) & $\because$ & 6 & $\begin{array}{l}\text { Tot } \\
\text { al }\end{array}$ & & & \\
\hline $\begin{array}{l}\text { Viorica } \\
\text { Dăncilă }\end{array}$ & $\begin{array}{l}\text { Change } \\
\text { profile } \\
\text { picture }\end{array}$ & Photo & $\begin{array}{l}21.09 . \\
2019 \\
\text { H } 15.10\end{array}$ & 436 & 98 & 101 & 3 & 6 & 52 & $\begin{array}{l}1 \\
756 \\
\end{array}$ & 2446 & 746 & \\
\hline $\begin{array}{l}\text { K. W. } \\
\text { Iohannis }\end{array}$ & $\begin{array}{l}\text { Submiss } \\
\text { ion of } \\
\text { candida } \\
\text { cy }\end{array}$ & $\begin{array}{l}\text { Messag } \\
\mathrm{e}+ \\
\text { photo }\end{array}$ & $\begin{array}{l}20.09 . \\
2019 \\
\text { H } 13.36\end{array}$ & $\begin{array}{l}4 \\
523\end{array}$ & 877 & 41 & 7 & 2 & 11 & $\begin{array}{l}7 \\
321\end{array}$ & 4500 & 1106 & \\
\hline $\begin{array}{l}\text { Al. } \\
\text { Cumpăn } \\
\text { așu }\end{array}$ & $\begin{array}{l}\text { Live } \\
\text { audienc } \\
\text { e } \\
\text { interacti } \\
\text { on }\end{array}$ & Live & $\begin{array}{l}08.10 . \\
2019 \\
\text { H } 22.00\end{array}$ & 400 & 000 & 300 & 57 & 03 & 11 & $\begin{array}{l}3 \\
000\end{array}$ & 37899 & 5915 & $\begin{array}{l}561 \\
632\end{array}$ \\
\hline
\end{tabular}

According to the analysis of distributions, it was noted that, to our surprise, Al. Cupănaşu outperforms the other two candidates both as a number of distributions, as reviews, as views, but also as a fan's commitment rate. It is noteworthy that one of the fans of Cumpănaşu shared the live analyzed above on no less than 39 groups that sum up 539144 people.

At K. W. Iohannis were noted two fans who redeployed in 5 large groups, amounting to 10650 people.

As for the candidate Viorica Dăncilă, in terms of redistribution by fans in large groups, two fans are distinguished, one with redistribution in a group of 201 people and one with redistribution in the ANTENA3 group, with 25968 people

Posts with the highest commitment rate following the motion (10-27 October 2019)

\begin{tabular}{|c|c|c|c|c|c|c|c|c|c|c|c|c|c|}
\hline \multirow{2}{*}{$\begin{array}{l}\text { Candid } \\
\text { ate }\end{array}$} & \multirow{2}{*}{$\begin{array}{l}\text { Subjec } \\
t\end{array}$} & \multirow{2}{*}{$\begin{array}{l}\text { Posti } \\
\text { ng } \\
\text { type }\end{array}$} & \multirow{2}{*}{$\begin{array}{l}\text { Dat } \\
\text { e/ } \\
\text { hour }\end{array}$} & \multicolumn{7}{|c|}{ Angajament } & \multirow{2}{*}{$\begin{array}{l}\text { Com } \\
\text { ments }\end{array}$} & \multirow{2}{*}{$\begin{array}{l}\text { Share } \\
\mathrm{s}\end{array}$} & \multirow{2}{*}{$\begin{array}{l}\text { Views } \\
\text { (meas } \\
\text { urable } \\
\text { only } \\
\text { in } \\
\text { live) }\end{array}$} \\
\hline & & & & לו & $\varphi$ & 3 & 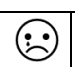 & $\theta$ & 6 & Total & & & \\
\hline $\begin{array}{l}\text { Viorica } \\
\text { Dăncilă }\end{array}$ & $\begin{array}{l}\text { Messa } \\
\text { ge } \\
\text { after } \\
\text { Motion }\end{array}$ & Status & $\begin{array}{l}10.1 \\
0.20 \\
19, \\
\mathrm{H} \\
14.1 \\
6\end{array}$ & $\begin{array}{l}450 \\
0\end{array}$ & 445 & 3100 & 77 & 35 & 202 & 8400 & 7200 & 998 & \\
\hline K. W. & Reupd & Photo & 17.1 & & & & & & & & & & \\
\hline
\end{tabular}


Vol. 1, 2019

\begin{tabular}{|c|c|c|c|c|c|c|c|c|c|c|c|c|c|}
\hline $\begin{array}{l}\text { Iohanni } \\
\text { s }\end{array}$ & $\begin{array}{l}\text { ate } \\
\text { profile } \\
\text { picture }\end{array}$ & & $\begin{array}{l}0.20 \\
19, \\
\mathrm{H} \\
08.0 \\
1 \\
\end{array}$ & $\begin{array}{l}340 \\
00\end{array}$ & $\begin{array}{l}220 \\
0\end{array}$ & 667 & 48 & 107 & 184 & $\begin{array}{l}3700 \\
0\end{array}$ & 2600 & 538 & \\
\hline $\begin{array}{l}\text { Al. } \\
\text { Cumpă } \\
\text { nașu }\end{array}$ & $\begin{array}{l}\text { Live } \\
\text { audien } \\
\text { ce } \\
\text { interac } \\
\text { tion }\end{array}$ & Live & $\begin{array}{l}14.1 \\
0.20 \\
19, \\
\mathrm{H} \\
19.4 \\
1\end{array}$ & $\begin{array}{l}570 \\
0\end{array}$ & $\begin{array}{l}160 \\
0\end{array}$ & 416 & 79 & 37 & 145 & 8000 & 18000 & 3300 & $\begin{array}{l}29752 \\
5\end{array}$ \\
\hline
\end{tabular}

Comparing the two periods, immediately after the motion can be noticed at Viorica Dăcila, per total page:

- Increase in the number of fans, from 613016 to 65103 fans

- Increase in the number of posts, from 35 (28 days precampaign, 1.25 post/day), to 33 (16 days campaign, 2.07 post/day)

- Increase in the number of reactions/comments/distributions, from 158157 (28 days Precampaign), 131688 (16 days campaign)

\section{References}

[1] Tasențe T. (2019) Social Media și comunicarea politică personalizată, Editura Universitară, București, 2019.

[2] Păun, M., \& Coman, C. (2010). The image of the public institutions and new technologies. Revista Romana de Jurnalism si Comunicare - Romanian Journal of Journalism and Communication, 33(4), 45-53. https://ideas.repec.org/a/foj/journl/y2010i4p45-53.html 